Uniwersytet Mikołaja Kopernika w Toruniu

Katedra Zarzadzania Finansami

\author{
Michał Buszko
}

\title{
RYNEK PRODUKTÓW STRUKTURYZOWANYCH CDO W WARUNKACH ŚWIATOWEGO KRYZYSU FINANSOWEGO
}

Z arys treści. W artykule przedstawiono istotę i funkcjonowanie nowoczesnych produktów strukturyzowanych CDO, opisano ich główne typy, konstrukcje oraz sposób emisji. Artykuł zawiera również analizę rynku CDO w latach 2004-2009, tzn. w okresie najszybszego rozwoju rozważanych produktów oraz jednocześnie w okresie narastającego kryzysu finansowego na świecie.

S ł o w a kluc z o w e: CDO, ryzyko kredytowe, subprime, sekurytyzacja, ocena ratingowa, aktywa bazowe.

\section{WSTĘP}

Współczesny rynek finansowy charakteryzuje się dynamicznymi przemianami, szybkim wprowadzaniem innowacyjnych instrumentów oraz nowoczesnych, coraz bardziej złożonych rozwiązań finansowych. Zmiany na rozważanym rynku są wynikiem zarówno pojawiania się nowych potrzeb w obszarze pozyskiwania kapitału, inwestowania oraz zarządzania ryzykiem, jak również poszukiwania coraz bardziej efektywnych metod osiagania zysków. Jednym z najbardziej znaczących i najszybciej rozwijających się obszarów światowego rynku finansowego w ostatnich latach był niewątpliwie segment produktów strukturyzowanych CDO (Collateralized Debt Obligations), tworzonych w procesie sekurytyzacji długu lub dłużnych papierów wartościowych. Pojawienie się CDO na światowym rynku finansowym stworzyło nową jakość w zakresie zarządzania ryzykiem 
kredytowym, umożliwiając innowacyjną strukturyzację, podział i sprzedaż tego ryzyka w transzach, a także jego dywersyfikację oraz rozproszenie w skali globalnej. Upowszechnienie produktów CDO przyczyniło się do odmiejscowienia ryzyka kredytowego oraz dało możliwość spekulacji kredytowej w skali globalnej. Czynnikiem, który istotnie wspomógł rozwój CDO na świecie, był bardzo szybki wzrost amerykańskiego rynku kredytów hipotecznych o podwyższonym ryzyku (subprime). Kredyty udzielane w Stanach Zjednoczonych osobom o niskiej zdolności kredytowej stały się powszechnie wykorzystywanymi aktywami bazowymi w CDO. Dzięki sprzedaży wspomnianych papierów wartościowych na amerykański rynek kredytów subprime napływało coraz więcej kapitału, a ryzyko z tego rynku było transferowane pomiędzy instytucje finansowe i spółki inwestycyjne w skali globalnej. Masowa skala niespłaconych kredytów subprime oraz głęboka recesja na amerykańskim rynku nieruchomości doprowadziły do załamania emisji CDO. Jednocześnie istniejące produkty CDO zaczęły generować bardzo duże straty, doprowadzając na skraj bankructwa część dużych instytucji finansowych. Z powodu utraty wartości CDO, sięgającej nawet całości nominału, instrumenty te zaczęto określać mianem toksycznych odpadów oraz nośników światowego kryzysu finansowego.

Ze względu na bardzo istotną rolę, jaką odegrały na światowym rynku finansowym produkty CDO w okresie 2004-2008, zarówno w roli instrumentów zarządzania ryzykiem, jak również instrumentów inwestycyjnych, celem niniejszego artykułu jest przedstawienie istoty i konstrukcji produktów CDO, scharakteryzowanie ich rynku oraz tendencji jego rozwoju. Niniejsze opracowanie przybliży również problem efektywności inwestowania na rynku CDO.

\section{PRODUKTY CDO - ISTOTA I FUNKCJONOWANIE}

CDO (Collateralized Debt Obligations) stanowią relatywnie nową i jednocześnie zróżnicowaną grupę produktów finansowych przeznaczonych dla inwestorów instytucjonalnych. Instrumenty te mają zazwyczaj formę dłużnych papierów wartościowych (obligacji), aczkolwiek mogą występować również w innych postaciach, np. certyfikatów czy akcji uprzywilejowanych. CDO mają zwykle długie terminy zapadalności wynoszące przeważnie od 4 do 12 lat, chociaż na rynku spotykane są produkty zarówno o terminach krótszych (1 rok), jak i dłuższych (do 40 lat) ${ }^{1}$.

1 Zob. Lancaster, Schultz, Fabozzi, 2008, s. 182. 
Produkty CDO należą do grupy papierów wartościowych tworzonych w procesach sekurytyzacji, sekrytyzacji syntetycznej lub resekurytyzacji aktywów finansowych - przede wszystkim długów lub dłużnych papierów wartościowych o niskiej płynności. Wykorzystanie procesów sekurytyzacji do emisji CDO oznacza, że wartość, rentowność oraz ryzyko tych produktów nie są związane z kondycją ekonomiczną oraz ryzykiem emitenta, ale zależą od parametrów finansowych i ekonomicznych aktywów bazowych, określanych mianem zabezpieczenia (collateral). W praktyce emisja papierów CDO wiąże się z koniecznością utworzenia przez inicjatora lub sponsora sekurytyzacji podmiotu celowego (SPV), który będzie prowadził obsługę rozliczeń związanych z portfelem aktywów bazowych, przeprowadzał emisje, a także prowadził rozliczenia wpływów i wypłat z tytułu CDO. W przypadku syntetycznych konstrukcji CDO podmiot SPV będzie dodatkowo występował w roli uczestnika swapów kredytowych, przyjmującego na siebie ryzyko referencyjnego portfela aktywów, oraz będzie reinwestował środki otrzymywane w następstwie emisji CDO².

Niezwykle istotnym aspektem związanym z tworzeniem produktów CDO jest dobór i konstrukcja portfela aktywów bazowych (zabezpieczenia). Portfel ten często budowany jest z pul jednorodnych rodzajowo aktywów, np. pożyczek korporacyjnych, hurtowych, dłużnych papierów wartościowych lub instrumentów finansowych powstałych w procesach sekurytyzacji. W skład portfela wchodzi przeważnie od kilkudziesięciu do kilku tysięcy instrumentów bazowych. CDO dywersyfikuje tym samym ryzyko pojedynczego instrumentu (długu), zastępując je cząstkowymi ryzykami generowanymi przez każdy z instrumentów portfela. Ważne jest przy tym, żeby ryzyka poszczególnych instrumentów nie były ze sobą skorelowane. Ryzyko inwestycyjne CDO w takiej sytuacji będzie odpowiadało średniemu ryzyku generowanemu przez daną klasę aktywów (długów).

Cechą charakterystyczną CDO jest również emitowanie tych produktów w transzach. Rozważane instrumenty tworzone są przeważnie na bazie aktywów (długów) o podwyższonym ryzyku kredytowym (np. na poziomie oceny BBB). Podwyższone ryzyko zabezpieczenia daje możliwość jego odpowiedniej strukturyzacji, pozwalającej na jednoczesną emisję CDO w transzach o różnych ocenach, począwszy od AAA, przez AA, A, BBB, a skończywszy na transzach bardzo ryzykownych bez nadanego ratingu (equity). Inwestorzy mają tym samym możliwość elastycznego dopasowania nabywanych instrumentów CDO do własnego profilu ryzyka.

2 Szerzej na temat rodzajów oraz zasad funkcjonowania SPV: Singer, 2001, s. 15-17. 


\section{KLASYFIKACJA ORAZ KONSTRUKCJA PRODUKTÓW CDO}

W ostatnich latach na rynku finansowym pojawiło się wiele odmian i konstrukcji produktów CDO. Główne typy CDO spotykane na światowym rynku finansowym przedstawia tabela 1.

Tabela 1. Klasyfikacja CDO

\begin{tabular}{|l|l|}
\hline \multicolumn{2}{|c|}{ CDO } \\
\hline Podział ze względu na rodzaj & CLO - oparte na długach hurtowych \\
aktywów bazowych & CBO - oparte na obligacjach \\
CXO - oparte na kursach walut \\
CCO - oparte na cenach towarów \\
CSO - oparte na aktywach syntetycznych \\
CFO - oparte na funduszach hedgingowych \\
CDO - oparte na innych CDO
\end{tabular}

Źródło: opracowanie własne.

Z punktu widzenia emitenta na szczególną uwagę zasługuje podział ze względu na sposób konstrukcji produktu. W tym obszarze można wyróżnić CDO konstruowane w sposób kasowy (tradycyjny) oraz syntetyczny. Konstrukcje kasowe wykorzystują rzeczywisty zakup aktywów bazowych przez podmiot SPV i transfer aktywów z bilansu aranżera. Konstrukcje syntetyczne wykorzystują transfer dochodów i ryzyka aktywów bazowych za pomocą kredytowych instrumentów 
pochodnych bez zmiany właściciela aktywów. Schemat 1 przedstawia sposób emisji i funkcjonowania kasowych (tradycyjnych) instrumentów CDO, natomiast schemat 2 sposób emisji i funkcjonowania syntetycznych CDO.

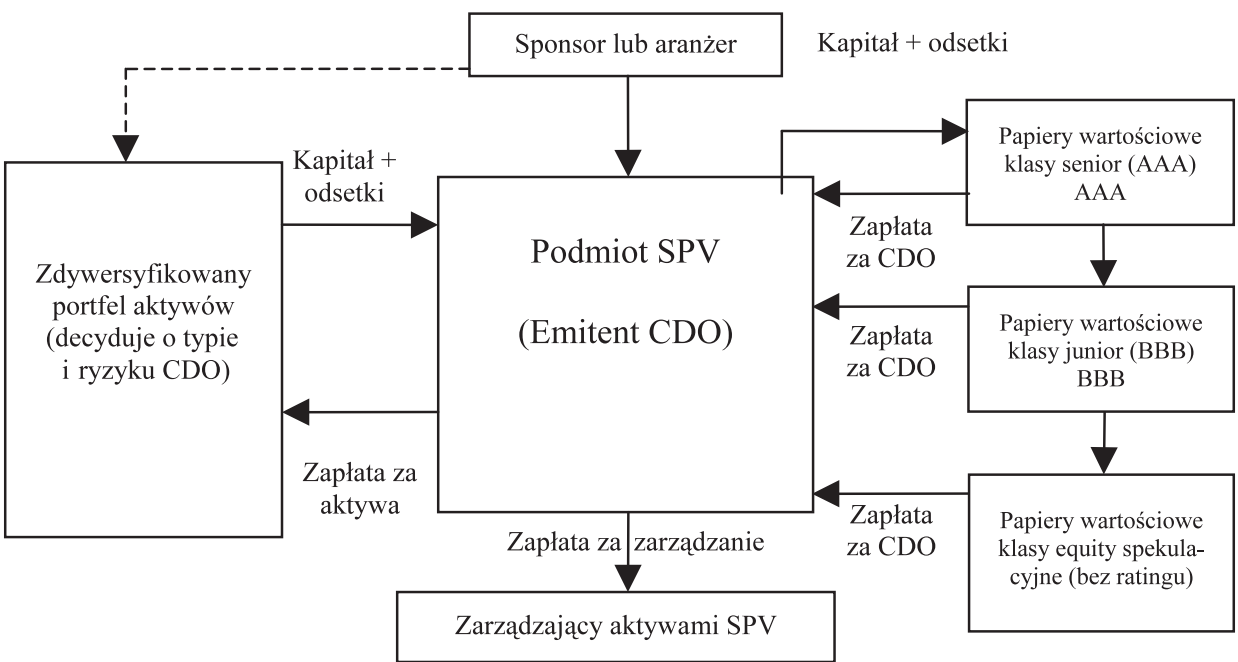

Schemat 1. Funkcjonowanie tradycyjnych CDO

Źródło: opracowanie własne na podstawie: Lancaster, Schultz, Fabozzi, 2008, s. 175.

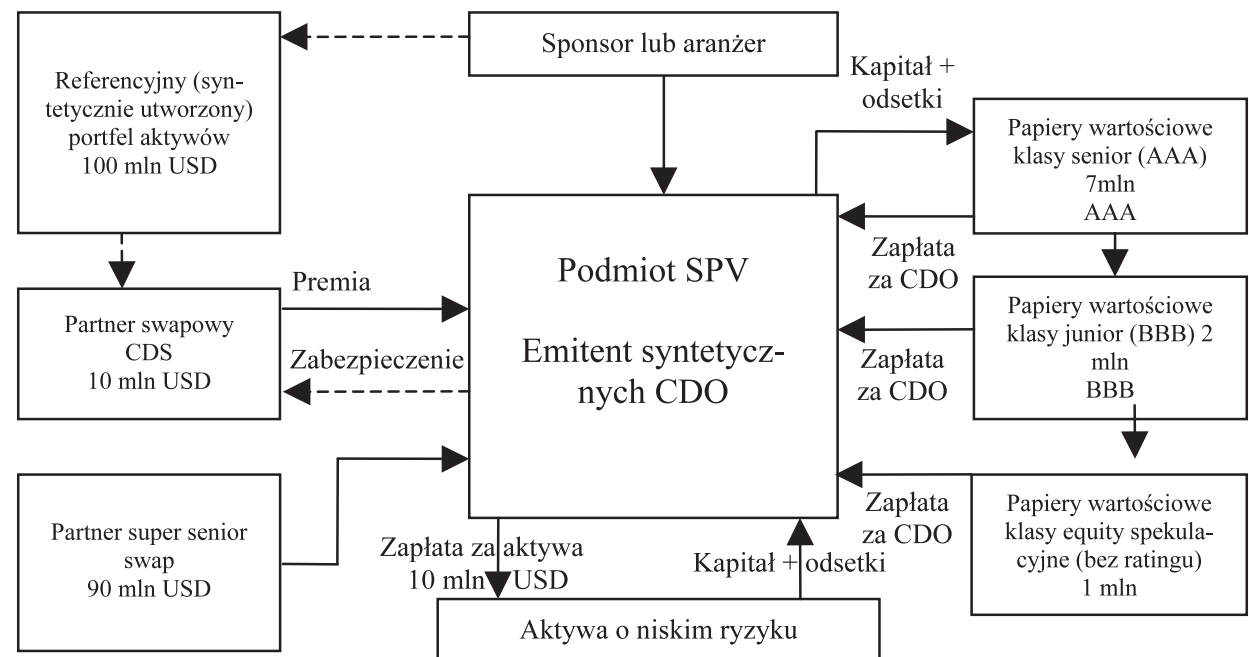

Schemat 2. Funkcjonowanie syntetycznych CDO

Źródło: opracowanie własne na podstawie: Fabozzi, Kothari, 2008, s. 237. 


\section{CDO A RYZYKO INWESTYCYJNE}

Jednym z najważniejszych aspektów związanych z inwestowaniem w produkty CDO jest ocena rozkładu prawdopodobieństwa oraz korelacji niewypłacalności dłużników, których pożyczki stanowią portfel zabezpieczający CDO. W zależności od oszacowanego ryzyka kredytowego emisje CDO dzielone są na transze o różnym ryzyku inwestycyjnym, a następnie podporządkowane w zakresie wypłat zysku oraz zwrotu inwestowanego kapitału ${ }^{3}$. Strukturyzacja oraz podporządkowany układ strumieni pieniężnych są cechami odróżniającymi CDO od innych instrumentów powstających w wyniku sekurytyzacji (ABS, MBS, CMBS, RMBS) lub sekurytyzacji syntetycznej (CLN). W praktyce, w celu ułatwienia inwestorom podjęcia decyzji dotyczącej zakupu odpowiednich do wymaganego profilu ryzyka produktów CDO, inicjator lub sponsor emisji występuje do jednej z uznanych na rynku globalnym agencji ratingowych o nadanie oceny dla każdej $\mathrm{z}$ transz. Transze o ocenie ratingowej AAA (określane jako senior) uznawane są za najbardziej bezpieczne, ale też najmniej dochodowe. Posiadacze instrumentów z wymienionej transzy uzyskują pierwszeństwo przy wypłacie dochodu oraz zwrocie zainwestowanego kapitału. Kwota zysku jest z góry określona (np. LIBOR + marża). W dalszej kolejności prawo do wypłaty dochodu oraz zwrotu kapitału uzyskują posiadacze transz o niższym ratingu, np. AA lub BBB. Transze te określane są mianem mezzanine lub junior. Dla wymienionych transz kwota zysku również jest ustalana z góry i jest wyższa w porównaniu do transz senior. Po zaspokojeniu roszczeń wymienionych dwóch grup inwestorów następuje wypłata zysku oraz zwrot kapitału posiadaczom transzy określanej jako equity ${ }^{4}$. Posiadacze papierów wartościowych tego typu otrzymują świadczenia jako ostatni, stąd porównuje się ich do akcjonariuszy spółki. Grupa ta w największym stopniu narażona jest na ryzyko strat, ale też może osiągnąć potencjalnie największy (lewarowany) zysk. Jego wartość nie jest określona z góry i zależy wyłącznie od rzeczywistej jakości aktywów bazowych (długów).

3 Zob. Fabozzi, Davis, Choudry, 2006, s. 122-123.

4 Transza equity nazywana jest także zero-equity, ponieważ oczekuje się, iż może wygenerować stratę w wysokości 100\% inwestowanego kapitału. Zob. Bessis, 2010, s. 64. 


\section{EMISJE CDO NA RYNKU ŚWIATOWYM}

Pierwsze produkty typu CDO pojawiły się na światowym rynku finansowym pod koniec lat $80 . \mathrm{XX} \mathrm{w.}{ }^{5}$ Początkowo emisje tych instrumentów oparte były przede wszystkim na pulach obligacji korporacyjnych o obniżonej jakości oraz w mniejszym stopniu na pożyczkach oraz innych tradycyjnych instrumentach dłużnych. Kryzys finansowy na rynkach wschodzących pod koniec XX w. oraz recesja gospodarki światowej na początku XXI w. istotnie wpłynęły na strukturę rynku CDO. Przede wszystkim w powyższych warunkach wystąpiło ograniczenie emisji CDO na podstawie obligacji korporacyjnych, które okazały się szczególnie wrażliwe na załamanie gospodarcze oraz podatne na obniżkę ocen ratingowych ${ }^{6}$. W tym samym czasie relatywnie odporne na kryzys okazały się CDO oparte na pożyczkach i kredytach, stąd stosunkowo szybko zdominowały one rynek produktów strukturyzowanych. Jednocześnie pojawiło się zapotrzebowanie na nowe konstrukcje CDO oraz rozpoczęto wykorzystywać w konstrukcjach CDO uprzednio sekurytyzowane instrumenty finansowe. Jako podstawę emisji zaczęto wykorzystywać instrumenty i tytuły dłużne emitowane przez fundusze inwestycyjne rynku nieruchomości, papiery wartościowe powstające w wyniku sekurytyzacji długów hipotecznych, obligacje komunalne czy papiery wartościowe dłużne powiązane z cenami walut, towarów lub innych aktywów niefinansowych. Przełomem w rozwoju rynku CDO było również pojawienie się pod koniec XX w. konstrukcji syntetycznych, które umożliwiały transfer oraz inwestowanie w ekspozycje kredytowe bez konieczności zakupu pul kredytów. Rozwiązanie takie umożliwiało przede wszystkim obniżkę kosztów przygotowania programów emisji CDO oraz tworzenie dowolnie dobranych portfeli aktywów referencyjnych, w tym dopasowanych do konkretnych potrzeb pojedynczych inwestorów. Niezwykle ważnym czynnikiem wspierającym ekspansję CDO na rynku światowym był bardzo szybki rozwój amerykańskiego rynku kredytów hipotecznych o podwyższonym ryzyku (subprime). Dzięki CDO banki amerykańskie już na początku XXI w. mogły rozpoczać transfer ryzyka pochodzącego z portfeli kredytów zagrożonych w skali globalnej. Ponieważ specyficzna konstrukcja CDO dawała możliwość tworzenia zróżnicowanych profili ryzyka inwestycyjnego, a także umożliwiała osiąganie wyższej rentowności na

5 Według internetowej encyklopedii Wikipedia pierwsza emisja CDO została przeprowadzona w 1987 r. przez bank inwestycyjny Drexel Burnham Lambert Inc. na zlecenie Imperial Savings Association. Szerzej na temat pierwszych lat funkcjonowania rynku CDO zob. Kothari, 2006, s. 417-419.

6 Zob. Hurst, 2002. 
tle tradycyjnych instrumentów dłużnych o tej samej ocenie ratingowej, stąd rozważane produkty bardzo szybko upowszechniły się na rynku światowym. Instrumenty emitowane w Stanach Zjednoczonych stały się istotnym celem zaangażowania banków zagranicznych, transferujących na rynek amerykański kapitał z innych części świata oraz jednocześnie przenoszących w skali globalnej ryzyko amerykańskich kredytów hipotecznych. Głównym centrum sprzedaży CDO stał się przy tym Nowy Jork. Emisje CDO w latach 2004-2009 osiagnęły odpowiednio: 157,8 mld USD, 251,3 mld USD, 520,6 mld USD, 481,6 mld USD, 61,9 mld USD, 0,8 mld USD 7 .

Dominację wśród emisji miały produkty kasowe, aczkolwiek na rynku uwidocznił się również znaczący udział grupy instrumentów tworzonych syntetycznie. Emisje syntetycznych CDO osiaggały w latach 2004-2009 następujące wartości: 35,8 mld USD, 44,4 mld USD, 66,5 mld USD, 48,5 mld USD, 1,3 mld USD, 104 mln USD, co stanowiło odpowiednio około: 23\%, 10\%, 13\%, 10\%, 2\% oraz 14\% łącznej wartości wszystkich $\mathrm{CDO}^{8}$.

Wartość emisji produktów CDO na światowym rynku finansowym w latach 2004-2009 $\mathrm{z}$ podziałem na statystyki kwartalne przedstawia wykres 1.

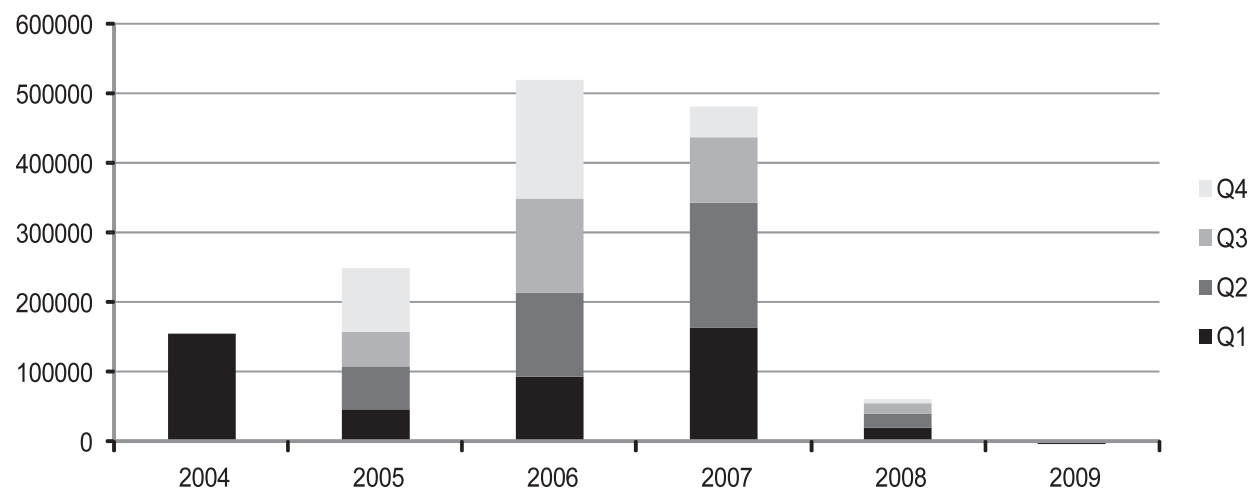

Wykres 1. Wartość emisji CDO na światowym rynku finansowym w tys. USD

Źródło: opracowanie własne na podstawie: Global CDO Data, Securities Industry and Financial Markets Association SIFMA, http://www.sifma.org, 10.06.09.

7 Dla porównania w tym samym okresie emisje dominujących w Stanach Zjednoczonych instrumentów dłużnych - obligacji zabezpieczonych kredytami hipotecznymi (mortgage-related) osiągnęły wartości: 1907,9 mld USD, 2222,2 mld USD, 2132,1 mld USD, 2146,1 mld USD, 1339,7 mld USD. Zob. Global CDO Data, Securities Industry and Financial Markets Association SIFMA, http://www.sifma.org, 10.06 .09 oraz Issuance in the U.S. Bond Markets, Securities Industry and Financial Markets Assiciation SIFMA, http://www.sifma.org, 10.06.09.

8 Tamże.

9 Dane za rok 2009 obejmują jedynie pierwszy kwartał. 
Generalnie, największe emisje papierów strukturyzowanych CDO odnotowano w czwartym kwartale 2006 r. oraz pierwszych dwóch kwartałach kolejnego roku. Pojawienie się symptomów kryzysu finansowego na amerykańskim rynku finansowym w połowie 2007 r. spowodowało gwałtowny spadek emisji CDO. Już w trzecim i czwartym kwartale tego samego roku emisje spadły do poziomów kwartalnych osiaganych dwa lata wcześniej. Rynek CDO, którego wartość szacowana była w 2007 r. na ok. 2 bln USD, uległ w 2008 r. dalszemu załamaniu. Część papierów wartościowych emitowanych na bazie pożyczek hipotecznych, w tym posiadających rating AAA, straciła całą swoją wartość ${ }^{10}$. Ogólna wartość emisji spadła o ok. 87\% w stosunku do roku poprzedniego, osiągając jednocześnie poziom 12\% wartości z rekordowego 2006 r. Rok 2009 potwierdził recesję na rynku CDO. W pierwszym kwartale dokonano emisji, które stanowiły zaledwie 4\% kwoty emisji pierwszego kwartału 2008 r. oraz około 0,4\% kwartalnej emisji z najlepszego - drugiego kwartału roku 2007.

Oceniając okres wykupu emitowanych CDO, należy wskazać, iż w latach 2004-2009 na rynku pojawiały się przede wszystkim produkty długoterminowe o zapadalności powyżej 18 miesięcy. Ich udział w emisjach ogółem wyniósł odpowiednio: w 2004 r. - 88\%, w 2005 r. - 97\%, w 2006 r. - 96\%, w 2007 r. 97\%. W 2008 oraz 2009 r. emisje miały charakter wyłącznie długoterminowy.

\section{CELE EMISJI CDO NA RYNKU ŚWIATOWYM}

Produkty strukturyzowane CDO emitowane są zasadniczo dla realizacji dwóch celów. Pierwszym z nich jest restrukturyzacja portfela aktywów bankowych aranżera emisji lub usunięcie z bilansu niepracujących lub niskodochodowych instrumentów. Produkty CDO umożliwiają w tym przypadku odzyskanie kapitału regulacyjnego oraz zapewniają rozwój działalności kredytowej, poprawę rentowności aktywów lub też wzrost płynności czy długoterminowej wypłacalności. Wymieniony cel emisji znajduje uzasadnienie przede wszystkim w bankach komercyjnych o dużych portfelach jednorodnych kredytów. Drugim celem przeprowadzania emisji CDO jest chęć osiągnięcia zysków arbitrażowych. Zyski arbitrażowe pojawiają się w sytuacji, gdy korzyści generowane przez aktywa bazowe (dług lub dłużne instrumenty finansowe) przewyższają koszty finansowania tych aktywów, tzn. koszty związane z emisją CDO oraz koszty działalności pomiotu SPV. Cel arbitrażowy znajduje uzasadnienie przede wszystkim w przypadku banków inwestycyjnych. Wykres 2 przedstawia udział poszczególnych rodzajów CDO (arbitrażowych i bilansowych) w łącznej emisji CDO.

10 Shenn, 2008. 

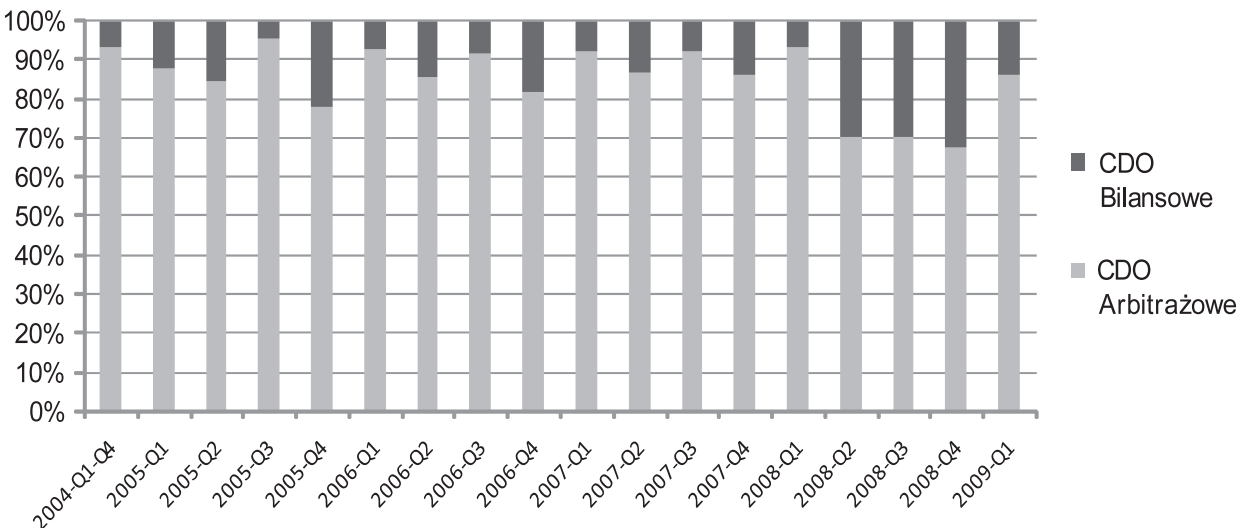

Wykres 2. Udział produktów bilansowych oraz arbitrażowych w emisjach CDO na rynku światowym

Źródło: opracowanie własne na podstawie: Global CDO Data, Securities Industry and Financial Markets Association SIFMA, http://www.sifma.org, 10.06.09.

Wykres 2 wskazuje, że na rynku światowym CDO upowszechniły się głównie ze względu na chęć osiągnięcia zysków przy wykorzystaniu inżynierii finansowej. Zarządzanie bilansem za pomocą CDO miało jednocześnie drugorzędne znaczenie. Jedynie okres od drugiego do czwartego kwartału 2008 r. uwidocznił wzrost znaczenia produktów bilansowych. Biorąc pod uwagę niezwykle wysoki spadek łącznej wartości emisji w 2008 r., zjawisko to należy przypisać przede wszystkim ograniczeniu zaangażowania banków na całym rynku CDO oraz odejściu od konstrukcji najbardziej ryzykownych, a nie szczególnemu wzrostowi zainteresowania CDO w procesie zarządzania pozycjami bilansowymi.

\section{AKTYWA BAZOWE CDO}

Produkty strukturyzowane CDO w praktyce emitowane są na podstawie różnych kategorii aktywów bazowych. Do ich powstania mogą być bezpośrednio wykorzystywane pożyczki czy kredyty, jak również proste bądź złożone dłużne (wierzycielskie) papiery wartościowe. W okresie 2004-2009 na rynku światowym widoczna była istotna zmiana udziału poszczególnych rodzajów instrumentów bazowych w programach emisji CDO. Wykres 3 przedstawia udział poszczególnych rodzajów aktywów w emisji CDO.

Analizując strukturę aktywów bazowych produktów CDO, można stwierdzić, że dominującą grupę dla ich emisji stanowią inne produkty strukturyzowane, 


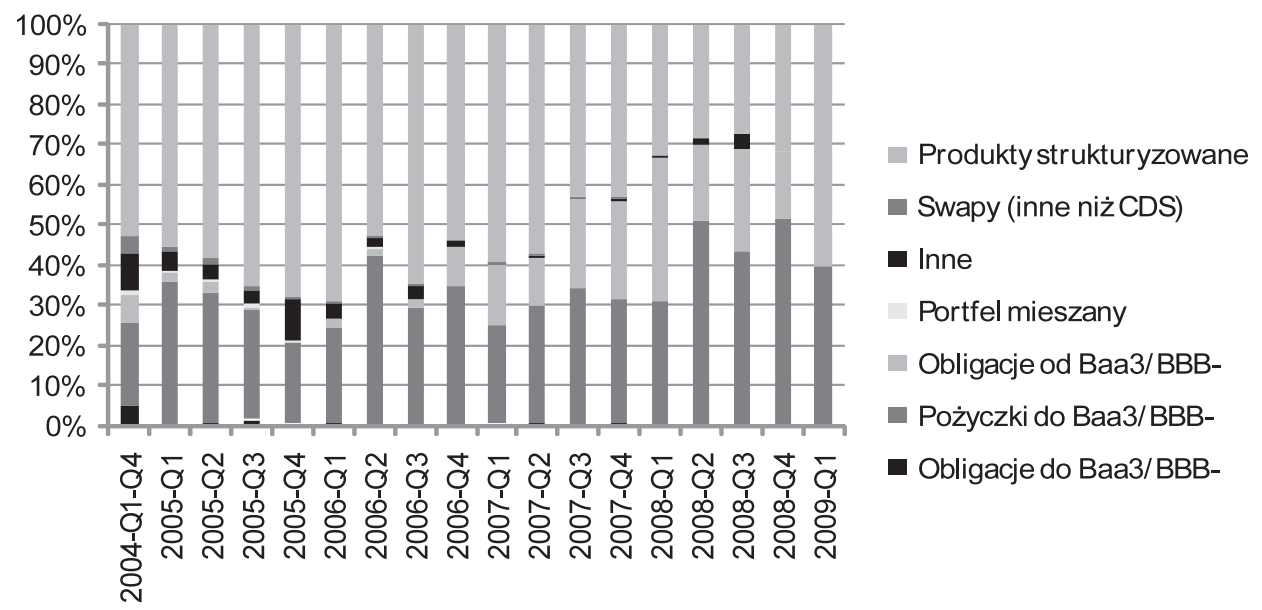

Wykres 3. Aktywa bazowe emisji CDO na rynku światowym

Źródło: opracowanie własne na podstawie: Global CDO Data, Securities Industry and Financial Markets Association SIFMA, http://www.sifma.org, 10.06.09.

takie jak: ABS, CMBS, RMBS, CDS, CMO oraz uprzednio wyemitowane CDO. Budowanie programów CDO na podstawie wymienionych powyżej instrumentów oznacza w praktyce resekurytyzację uprzednio sekurytyzowanych aktywów. Powtórna sekurytyzacja niewątpliwie istotnie komplikuje oszacowanie rzeczywistego ryzyka inwestycyjnego związanego z produktami CDO oraz utrudnia ich wycenę. W przypadku ograniczonej płynności rynku może przyczyniać się ona także do występowania gwałtownych spadków wartości CDO na skutek obniżenia jakości aktywów bazowych. O znaczeniu ryzyka resekurytyzacji w konstrukcjach CDO opartych na innych produktach strukturyzowanych może świadczyć znaczne ograniczenie emisji takich instrumentów w 2008 r. oraz ich całkowite wstrzymanie w pierwszym kwartale 2009 r. Kolejną grupą aktywów powszechnie wykorzystywanych w konstrukcji CDO były pożyczki i kredyty o podwyższonym stopniu ryzyka (o ocenie ratingowej Baa3/BBB-) zaciagane przede wszystkim przez przedsiębiorstwa. W praktyce CDO umożliwiały efektywną strukturyzację ryzyka tych aktywów, co powodowało, że inwestowanie w produkty strukturyzowane oparte na kredytach okazywało się znacznie mniej ryzykowne od inwestowania w obligacje korporacyjne ${ }^{11}$. W 2007 oraz 2008 roku coraz większy udział zaczęły koncentrować produkty emitowane na bazie obligacji lepszej

\footnotetext{
11 Zob. tabela 2.
} 
jakości posiadające inwestycyjną ocenę ratingową (powyżej Baa3/BBB-). Aktywa te zdominowały emisje CDO w pierwszym kwartale 2009 r., co wiązało się z poszukiwaniem mniej ryzykownych konstrukcji w warunkach kryzysu na rynku światowym.

\section{WALUTY EMISJI CDO}

Ze względu na specyfikę emisji produktów CDO oraz ich przeznaczenie przede wszystkim dla dużych inwestorów instytucjonalnych (banków inwestycyjnych, komercyjnych, towarzystw ubezpieczeniowych, funduszy hedgingowych, podmiotów asset management) prowadzących działalność w skali ogólnoświatowej, rynek CDO powinien być analizowany w takim właśnie kontekście, a nie pod kątem wartości emisji w poszczególnych krajach. W praktyce produkty CDO często charakteryzują się znacznym umiędzynarodowieniem, tzn. mogą być emitowane w jednym kraju na bazie zabezpieczenia zlokalizowanego w kraju drugim, w walucie kraju trzeciego. W przypadku rynku CDO najczęściej rozważany jest podział instrumentów według walut emisji. W tym obszarze do 2008 r. podstawową walutą produktów CDO był dolar amerykański. Trudna sytuacja na rynku bankowym w Stanach Zjednoczonych oraz poszukiwanie kapitałów na rynku europejskim spowodowały wzrost znaczenia euro od 3 kwartału 2007 r. Inne waluty emisji CDO to jen japoński, funt brytyjski oraz dolar australijski. Wykres 4 przedstawia strukturę walut, w jakich emitowano CDO na rynku światowym.

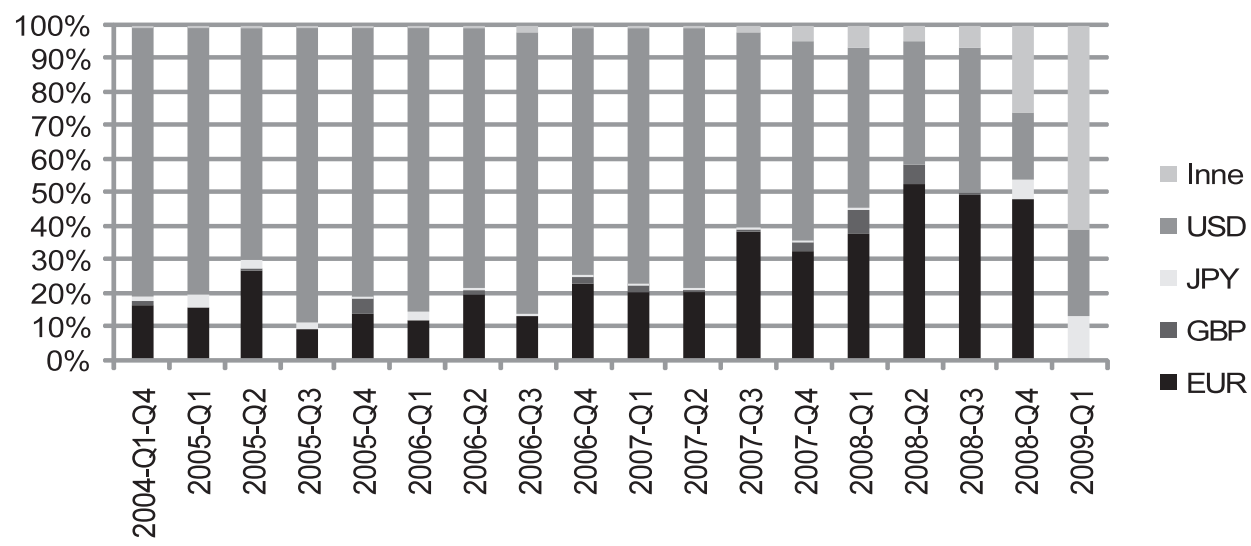

Wykres 4. Waluty emisji CDO

Źródło: opracowanie własne na podstawie: Global CDO Data, Securities Industry and Financial Markets Association SIFMA, http://www.sifma.org, 10.06.09. 


\section{EFEKTYWNOŚĆ INWESTOWANIA NA RYNKU CDO}

Ocena efektywności inwestowania na rynku instrumentów CDO jest zadaniem relatywnie trudnym. Podstawowym problemem w tym przypadku jest brak zorganizowanego płynnego rynku wtórnego dla tych produktów, umożliwiającego dokonanie ich bieżącej wyceny. Ponieważ produkty CDO nie są notowane na giełdzie, nie jest możliwa ich analiza w krótkim okresie ani szybkie ustalenie tendencji w zakresie zmiany ich wartości. O ile popyt na produkty CDO w latach 2004-2007 istotnie zwiększał się, o tyle transakcje kupna-sprzedaży tych instrumentów odbywały się praktycznie wyłącznie na rynku pierwotnym. Ze względu na specyficzną strukturyzację ryzyka i dochodów tych instrumentów ich wycena była przeprowadzana właściwie jedynie na bazie modeli matematycznych opracowanych przez niezależne agencje ratingowe. Problem braku rozwiniętego rynku wtórnego CDO okazał się szczególnie istotny w 2008 r., kiedy na światowym rynku finansowym doszło do pojawienia się kryzysu płynności banków. Instytucje finansowe posiadające CDO nie były w stanie ich odsprzedać, co powodowało konieczność dokonywania przez nie odpisów wartości oraz pokrywania coraz większych strat z tytułu inwestycji na rynku CDO. Ze względu na bardzo dużą skalę niespłaconych kredytów subprime wyemitowane na ich podstawie papiery wartościowe RMBS, a następnie CDO zaczęto określać jako tzw. odpady toksyczne.

Ze względu na brak wyceny CDO na zorganizowanych rynkach, brak giełdowych notowań dla tych instrumentów, jak również brak odpowiednich benchmarków oraz indeksów cen, efektywność inwestowania w produkty strukturyzowane pochodzące z procesów sekurytyzacji można ocenić za pomocą zmiany ich ocen ratingowych. Powyższe podejście nie jest pozbawione wad, ponieważ opiera się na teoretycznych modelach wyceny, niemniej umożliwia ustalenie generalnej

Tabela 2. Prawdopodobieństwo obniżenia oceny ratingowej dla różnych rodzajów CDO

\begin{tabular}{|l|c|c|c|c|c|c|c|}
\hline Rating & $\begin{array}{c}\text { Arbitrażo- } \\
\text { we CBO }\end{array}$ & $\begin{array}{c}\text { Arbitrażo- } \\
\text { we CLO }\end{array}$ & $\begin{array}{c}\text { Oparte na prod. } \\
\text { strukturyzowanych }\end{array}$ & $\begin{array}{c}\text { Arbitrażowe } \\
\text { syntez. (USD) }\end{array}$ & $\begin{array}{c}\text { Arbitrażowe } \\
\text { syntet. inne }\end{array}$ & $\begin{array}{c}\text { CDO } \\
\text { ogółem }\end{array}$ & $\begin{array}{c}\text { Obligacje } \\
\text { korporacyjne }\end{array}$ \\
\hline Aaa & $1,2 \%$ & $0,0 \%$ & $8,0 \%$ & $1,3 \%$ & $0,8 \%$ & $4,0 \%$ & $5,1 \%$ \\
\hline Aa2 & $0,0 \%$ & $0,0 \%$ & $17,6 \%$ & $1,9 \%$ & $0,0 \%$ & $8,3 \%$ & $4,6 \%$ \\
\hline Baa2 & $0,0 \%$ & $0,3 \%$ & $37,5 \%$ & $1,5 \%$ & $0,0 \%$ & $17,4 \%$ & $6,0 \%$ \\
\hline Baa3 & $17,6 \%$ & $0,0 \%$ & $57,5 \%$ & $8,6 \%$ & $0,0 \%$ & $27,6 \%$ & $4,2 \%$ \\
\hline Ba2 & $7,7 \%$ & $0,0 \%$ & $39,3 \%$ & $0,0 \%$ & $25,0 \%$ & $7,5 \%$ & $15,4 \%$ \\
\hline Ba3 & $22,2 \%$ & $12,5 \%$ & $25,0 \%$ & $0,0 \%$ & $0,0 \%$ & $14,0 \%$ & $11,2 \%$ \\
\hline
\end{tabular}

Źródło: Credit migration of CDO notes, 1996-2007, for US and European transact. Structured Finance. Special Report, Moody’s Investor Service, 31 March, 2008. 
tendencji w zakresie zmian wartości i ryzyka inwestycyjnego produktów strukturyzowanych.

Do oceny efektywności inwestowania w poszczególne rodzaje i transze produktów CDO można wykorzystać analizę rozkładu prawdopodobieństwa obniżki oceny ratingowej. Przykładowe zestawienie rozkładów opracowane przez agencję Moody’s Investor Service dla produktów CDO oraz obligacji korporacyjnych ocenianych w 2007 r. przedstawia tabela 2 (zob. s. 153).

Na podstawie zaprezentowanych w niej danych widoczne jest zwłaszcza wysokie ryzyko inwestowania w CDO oparte na innych produktach strukturyzowanych. Wynik ten jest potwierdzeniem bardzo głębokiej recesji na rynku papierów wartościowych zabezpieczonych kredytami subprime (RMBS) ${ }^{12}$.

Tabela 3. Zmiana ocen ratingowych CDO denominowanych w EUR

\begin{tabular}{|c|c|c|c|c|c|c|c|}
\hline \multicolumn{7}{|c|}{ Fitch Ratings } \\
\hline Rok & CDO & $\begin{array}{c}\text { Pożyczki } \\
\text { samochodowe }\end{array}$ & $\begin{array}{c}\text { Karty } \\
\text { kredytowe }\end{array}$ & Inne ABS & CMBS & RMBS & $\begin{array}{c}\text { RMBS } \\
\text { (zagrożone) }\end{array}$ \\
\hline 2007 & $+92 /-80$ & $+6 / 0$ & $0 / 0$ & $+31 /-17$ & $+66 /-10$ & $+200 /-6$ & $+85 /-1$ \\
\hline 2008 & $+12 /-697$ & $+4 /-6$ & $0 /-9$ & $+12 /-41$ & $+19 /-75$ & $+73 /-67$ & $+64 /-279$ \\
\hline \multicolumn{7}{|c|}{ Moody's Investor Service } \\
\hline Rok & CDO & $\begin{array}{c}\text { Pożyczki } \\
\text { samochodowe }\end{array}$ & $\begin{array}{c}\text { Karty } \\
\text { kredytowe }\end{array}$ & Inne ABS & CMBS & RMBS & $\begin{array}{c}\text { RMBS } \\
\text { (zagrożone) }\end{array}$ \\
\hline 2007 & $+215 /-235$ & $+1 / 0$ & $0 / 0$ & - & $+42 /-6$ & $+18 /-1$ & $+6 /-8$ \\
\hline 2008 & $+77 /-2134$ & $+2 /-4$ & $3 /-22$ & - & $+11 /-77$ & $0 /-74$ & $+5 /-171$ \\
\hline \multicolumn{7}{|c|}{ Standard \& Poor's } \\
\hline Rok & CDO & $\begin{array}{c}\text { Pożyczki } \\
\text { samochodowe }\end{array}$ & $\begin{array}{c}\text { Karty } \\
\text { kredytowe }\end{array}$ & Inne ABS & CMBS & RMBS & $\begin{array}{c}\text { RMBS } \\
\text { (zagrożone) }\end{array}$ \\
\hline 2007 & $+207 /-331$ & $+2 / 0$ & $0 / 0$ & - & $+46 /-15$ & $+67 /-6$ & $+16 / 0$ \\
\hline 2008 & $+121 /-3059$ & $+12 /-10$ & $0 / 0$ & - & $+15 /-103$ & $+39 /-88$ & $+29 /-123$ \\
\hline
\end{tabular}

Źródło: opracowanie własne na podstawie: ESF Securitisation Data Report Q4:2008, European Securitization Forum, Securities Industry and Financial Markets Association SIFMA, http://www.sifma.org, 10.06.09.

12 W 2007 r. Moody’s Investor Service dokonał 1331 obniżek ocen ratingowych transz CDO opartych na papierach wartościowych zabezpieczonych kredytami subprime. Stanowiło to łącznie 92\% wszystkich negatywnych zmian ocen ratingowych transz CDO dokonanych przez wymienioną agencję. Spośród 1331 obniżek ocen 596 dotyczyło transz CDO wyemitowanych w 2006 r. oraz 661 wyemitowanych w 2007 r. Dla porównania średnia liczba zmian ocen na niższą dla CDO emitowanych w latach 2000-2005 kształtowała się od 4 do 16. Wynik ten potwierdza skalę problemu kredytów subprime i ryzyka związanych z nimi CDO, wyemitowanych w ostatnich dwóch latach. Zob. Credit migration of CDO notes, 1996-2007, for US and European transact. Structured Finance. Special Report, Moody’s Investor Service, 31 March, 2008. 
Tabela 4. Zmiana ocen ratingowych CDO denominowanych w USD

\begin{tabular}{|c|c|c|c|c|c|c|c|c|}
\hline \multicolumn{7}{|c|}{ Fitch Ratings } \\
\hline Rok & CDO & $\begin{array}{c}\text { Pożyczki } \\
\text { samocho- } \\
\text { dowe }\end{array}$ & $\begin{array}{c}\text { Karty } \\
\text { kredytowe }\end{array}$ & Inne ABS & CMBS & $\begin{array}{c}\text { RMBS } \\
\text { (rime) }\end{array}$ & $\begin{array}{c}\text { RMBS } \\
\text { (subprime) })\end{array}$ & Inne RMBS \\
\hline 2007 & $+218 /-1180$ & $+95 / 0$ & $+14 /-2$ & $+125 /-60$ & $+776 /-70$ & $+177 /-23$ & $+267 /-3729$ & $+86 /-252$ \\
\hline 2008 & $+28 /-1705$ & $+36 /-64$ & $+1 /-22$ & $+270 /-775$ & $+297 /-473$ & $+13 /-2096$ & $0 /-10861$ & $+73 /-11679$ \\
\hline \multicolumn{7}{|c|}{ Moody's Investor Service } \\
\hline Rok & CDO & $\begin{array}{c}\text { Pożyczki } \\
\text { samocho- } \\
\text { dowe }\end{array}$ & $\begin{array}{c}\text { Karty } \\
\text { kredytowe }\end{array}$ & Inne ABS & CMBS & \multicolumn{3}{|c|}{ RMBS } \\
\hline 2007 & $+111 /-1526$ & $+93 / 0$ & $+68 / 0$ & - & $+877 /-77$ & \multicolumn{2}{|c|}{$+454 /-8052$} \\
\hline 2008 & $+91 /-8742$ & $+29 /-255$ & $0 /-46$ & - & $+449 /-439$ & \multicolumn{2}{|c|}{$+294 /-40083$} \\
\hline \multicolumn{7}{|c|}{ Standard \& Poor's } \\
\hline Rok & CDO & $\begin{array}{c}\text { Pożyczki } \\
\text { samocho- } \\
\text { dowe }\end{array}$ & $\begin{array}{c}\text { Karty } \\
\text { kredytowe }\end{array}$ & Inne ABS & CMBS & RMBS (prime) & RMBS (subprime) \\
\hline 2007 & $+304 /-1692$ & $+124 /-2$ & $+68 /-3$ & - & $+648 /-128$ & $+332 /-44$ & $+55 /-4668$ \\
\hline 2008 & $+253 /-10442$ & $+26 /-167$ & $0 /-20$ & - & $+189 /-944$ & $+157 /-1478$ & $+38 /-12959$ \\
\hline
\end{tabular}

Źródło: opracowanie własne na podstawie: ESF Securitisation Data Report Q4:2008, European Securitization Forum, Securities Industry and Financial Markets Association SIFMA, http://www.sifma.org, 10.06.09.

Analizując efektywność inwestowania na światowym rynku CDO, warto również przyjrzeć się liczbie pozytywnych i negatywnych zmian ocen ratingowych dokonywanych przez agencje ratingowe $\mathrm{z}$ uwzględnieniem podziału na waluty. Zmiany ocen nadawanych produktom CDO denominowanym w euro przedstawia tabela 3 (zob. s. 154), natomiast zmiany ocen produktów CDO denominowanych w USD przedstawia tabela $4^{13}$.

Na rynku europejskim papiery wartościowe CDO w latach 2007-2008 okazały się najmniej efektywnym rodzajem inwestycji spośród wszystkich instrumentów utworzonych w procesach sekurytyzacji i ocenianych przez agencje ratingowe. W rozważanym okresie dokonano łącznie 724 zmian ocen inwestycyjnych na wyższe oraz 6536 obniżek. Stosunkowo duża liczba negatywnych zmian ocen ratingowych CDO na tle innych instrumentów strukturyzowanych, których zabezpieczeniem były aktywa zlokalizowane w Europie, może wynikać z braku na rynku europejskim segmentu kredytów będących odpowiednikiem amerykańskiego segmentu subprime. Należy również mieć na uwadze, że CDO rynku europejskiego obejmują wszystkie papiery denominowane w euro

13 Pierwsza wartość oznacza liczbę zmian ocen na wyższą, natomiast druga oznacza liczbę zmian ocen na niższą. 
niezależnie od miejsca pochodzenia zabezpieczenia, co w praktyce oznacza możliwość zawierania się w tej grupie CDO emitowanych na bazie amerykańskich długów o obniżonej jakości.

Na tle rynku europejskiego w Stanach Zjednoczonych najczęściej obniżana była ocena ratingowa papierów wartościowych opartych na długach hipotecznych finansujących nieruchomości mieszkaniowe (RMBS). Należy jednak pamiętać, że niezwykle często podstawą emisji CDO były w wymienionym okresie właśnie RMBS, co w praktyce oznaczało przenoszenie ryzyka pomiędzy wymienionymi rodzajami instrumentów. W Stanach Zjednoczonych w rozważanych latach dokonano 1005 zmian ocen ratingowych CDO na wyższe, natomiast aż 25287 ocen obniżono.

\section{PODSUMOWANIE}

Produkty strukturyzowane CDO odegrały w ostatnich latach bardzo znaczącą rolę. Z jednej strony, przyczyniły się do rozwoju inżynierii finansowej, obszaru finansów strukturyzowanych, technik zarządzania ryzykiem kredytowym i wpłynęły na ożywienie rynku tradycyjnych instrumentów dłużnych. Z drugiej zaś, CDO spowodowały odmiejscowienie oraz niekontrolowany transfer ryzyka kredytowego w skali światowej. Dzięki nim przeciwdziałanie pojawieniu się kryzysu światowego było praktycznie niemożliwe. Rozważane produkty uniemożliwiały bowiem ocenę, kto, w jakim stopniu oraz o jakiej wartości nabywa ryzyko kredytowe. Ich niska transparentność oraz bardzo duża skala niespłaconych kredytów subprime spowodowały wygenerowanie gigantycznych strat przez wiele instytucji finansowych o znaczeniu globalnym. W Stanach Zjednoczonych, gdzie programy CDO rozwinęły się najbardziej, podmioty, takie jak: Countrywide Financial, Washington Mutual, Bear Stearns, Merrill Lynch, Lehman Brothers, Morgan Stanley, AIG, znalazły się na krawędzi bankructwa, zbankrutowały lub zostały przejęte. Regulacje ostrożnościowe stosowane zarówno na rynku europejskim, jak i amerykańskim okazały się nieskuteczne w zapobieganiu rozprzestrzeniania się strat pomiędzy bankami na świecie. Również nieskuteczne okazały się modele wyceny CDO opracowywane na podstawie historycznych, zupełnie odmiennych od współczesnych warunków rynkowych. Rozpowszechnienie kryzysu finansowego w skali światowej było niewątpliwie również konsekwencją zbyt dużego zaufania, jakim inwestorzy, zwłaszcza instytucjonalni, obdarzyli agencje ratingowe. 


\section{LITERATURA}

Bessis J. (2010), Risk management in banking, John Wiley \& Sons, Chichester.

Credit migration of CDO notes, 1996-2007, for US and European transact. Structured

Finance. Special Report, Moody’s Investor Service, 31 March, 2008.

ESF Securitisation Data Report Q4:2008, European Securitization Forum, Securities

Industry and Financial Markets Association SIFMA, http://www.sifma.org.

Fabozzi F. J., Davis H. A., Choudry M. (2006), Introduction to Structured Finance, John

Wiley \& Sons, New Jersey.

Fabozzi F., Kothari V. (2008), Introduction to Securitization, John Wiley \& Sons, New Jersey. Global CDO Data, Securities Industry and Financial Markets Association SIFMA, http://www.sifma.org.

Hurst R. R. (2002), Downgrade after downgrade. Why are investors still buying CDOs?, Bank One Capital Markets, Inc., 1 August.

Issuance in the U.S. Bond Markets, Securities Industry and Financial Markets Association SIFMA, http://www.sifma.org.

Kothari V. (2006), Securitization. The financial instrument of the future, John Wiley \& Sons (Asia), Singapore.

Lancaster B. P., Schultz G. M., Fabozzi F. J. (2008), Structured products and related credit derivatives. A comprehensive guide for investors, John Wiley \& Sons, New Jersey. Shenn J. (2008), CDO Market Is Almost Frozen, JPMorgan, Merrill Say, Bloomberg.com, 5 February.

Singer D. (2001), Securitization basics, [w:] Fabozzi F. J. (red.), Accessing capital markets through securitization, Frank J. Fabozzi Associates, Pennsylvania.

\section{MARKET OF CDO STRUCTURED PRODUCTS IN TERMS OF WORLD FINANCIAL CRISIS}

Abstract: Collateralized debt obligations (CDO) are new, innovative products available to institutional investors on the global financial markets. Their development is strictly related to the subprime loans expansion. In the recent years CDO have become a financial tool of transferring worldwide a risk of American mortgage loan market. In fact, due to CDO such transfer was enormous and uncontrolled. As CDO are not transparent nor they are traded at stock exchange, their valuation and performance assessment are very difficult. In practice, very fast growth of subprime loans in US boosted development of CDO on global financial market. On the other hand, the mentioned structured products supplied capital to subprime segment, increasing the amount of non-conforming loans and hence the risk level in the global financial sector. Because CDO played significant role in the credit risk proliferating and generation of enormous losses among biggest investment and commercial banks, the aim of this paper is to present the idea, nature and mode of functioning of CDO. Also, the paper describes the CDO market in terms of world financial crisis.

K e y w o r d s : CDO, credit risk, subprime, securitizaton, credit rating, collateral. 